\title{
SPATIAL ARRANGEMENTS FOR SUPER-EARLY GENOTYPES FOR COMMON BEAN PRODUCTION
}

Vitor Henrique Vaz Mondo', Adriano Stephan Nascente ${ }^{2}$

EMBRAPA, Produtos e Mercados em Campinas, SP. EMBRAPA, Arroz e Feijão em Santo Antônio de Goiás, GO. Email: adriano.nascente@embrapa.br

\begin{abstract}
The super-early genotypes (SEG) of common bean, developed by Embrapa Rice and Beans in Brazil, have a shorter life cycle (65-75 days) when compared with the full-season traditional cultivars (95-105 days). Spatial arrangements of plants for SEG should be evaluated to allow fully exploit of its genetic potential. The aim of this study was to determine the effects of plant population and row spacing on grain yield and its components in super-early genotypes of common bean. The experimental design was a randomized block in a $2 \times 2 \times 5$ factorial, with six replications, in two growing seasons (summer 2014/2015 and winter 2015). The treatments consisted of the combination of two super-early genotypes of common bean (CNFC 15874 and CNFC 15875), two row spacings ( 0.35 and $0.45 \mathrm{~m})$ and five plant densities $(6,10,14,18$ and 22 seeds $\mathrm{m}^{-1}$ ). We also included a control treatment, IPR Colibri cultivar (65-75 days of life cycle) with 10 seeds $\mathrm{m}^{-1}$ density. The increase in plant density decreased yield components per plant but increased grain yield of super-early genotypes of common bean per unit area (from 1653 to $4614 \mathrm{~kg} \mathrm{ha}^{-1}$ in summer 2014/2015 and from 2239 to $2537 \mathrm{~kg} \mathrm{ha}^{-1}$ in winter 2015). The spatial arrangement of sowing density of 22 seeds per meter and $0.45 \mathrm{~m}$ row spacing allowed the highest grain yield in super-early genotypes of common bean.

Keywords: Phaseolus vulgaris; sowing density; plant grown; grain yield.
\end{abstract}

\section{ARRANJOS ESPACIAIS PARA PRODUÇÃO DE GENÓTIPOS SUPER-PRECOCES DE FEIJÃO-COMUM}

\section{RESUMO}

Os genótipos super-precoces (GSP) de feijão-comum, desenvolvido pela Embrapa Arroz e Feijão, tem um ciclo mais curto (65-75 dias) quando comparado com cultivares tradicionais de ciclo normal (95-105 dias). Arranjos espaciais de plantas para GSP devem ser avaliados para explorar o seu máximo potencial genético. O objetivo deste estudo foi determinar os efeitos da população de plantas e espaçamento entre linhas na produtividade e nos componentes de produção de genótipos super-precoces de feijão-comum. 0 delineamento experimental foi em blocos casualizados, em esquema fatorial $2 \times 2 \times 5$, com seis repetições, em dois anos agrícolas (verão 2014/2015 e inverno 2015). Os tratamentos consistiram da combinação de dois genótipos super-precoces de feijão-comum (CNFC 15874 e CNFC 15875), dois espaçamentos entre linhas $(0.35$ e $0.45 \mathrm{~m})$ e cinco densidades de sementes na linha $\left(6,10,14,18\right.$ e 22 sementes $\left.\mathrm{m}^{-1}\right)$. Também foi incluído um tratamento controle, o IPR Colibri (65-75 dias de ciclo), com densidade de 10 sementes por metro. $\mathrm{O}$ aumento da densidade de sementes por metro proporcionou redução dos componentes de produção dos genótipos super-precoces de feijão-comum, mas aumentou a produtividade de grãos dos genótipos super-precoces de feijão-comum por área (de 1653 para $4614 \mathrm{~kg} \mathrm{ha}^{-1}$ no verão 2014/2015 e de 2239 para $2537 \mathrm{~kg} \mathrm{ha}^{-1}$ no inverno 2015). O arranjo espacial de densidade de semeadura de 22 sementes por metro e $0.45 \mathrm{~m}$ de espaçamento entre linhas permitiu as maiores produtividades dos genótipos superprecoces de feijão-comum.

Palavras-chave: densidade de semeadura; cultivo de plantas; Phaseolus vulgaris; produtividade.

The common bean (Phaseolus vulgaris L.) is a crop with great economic and social importance in many countries and the main source of plant protein in human diet . In 2014,
25 million $\mathrm{Mg}$ of common bean were produced worldwide, with the main producers being India (4.2 million Mg), Myanmar (3.7 million Mg), Brazil (3.3 million Mg), USA (1.3 million Mg) and Mexico 
(1.3 million Mg) (FAOSTAT, 2016). These data make this crop the third most produced crop in Brazil, after soybeans and maize (CONAB, 2016). The average productivity of common bean grains in Brazil in the 2015/2016 growing season reached $1050 \mathrm{~kg} \mathrm{ha}^{-1}$, however, there are regions where grain yield reached $3362 \mathrm{~kg} \mathrm{ha}^{-1}$ (CONAB, 2016).

The use of super-early genotypes (SEG) of common bean would allow achieving high grain yields in a short time, thus providing irrigation water and power savings and hence reducing the cost of production (NASCENTE; MELO, 2016). This technology would also allow best land use, such as cultivation of two crops during the rainy season, or even up to three crops during the same year in irrigated areas (NASCENTE; MELO, 2015). For rainfed season, the SEG can escape drought periods when sown late, once is very common to have dry spell in January. Besides, the use of SEG would reduce costs and production risks, since a variety with shorter life cycle could provide a faster removal of the crop from the field. Therefore, the crop becomes less subject to attacks by insects, diseases, and weeds. Producing more food in a shorter time is very important for many developing countries, such as the Latin America and Eastern and Southern Africa, which use the grain of this crop in their daily human diets (ROSALES-SERNA et al., 2004). Grain yield of common bean crop is influenced by many factors, such as disease, pests, weeds, mineral nutrition, environmental conditions, and planting density (SOUZA et al., 2014). The use of improved cultural practices has enabled significant increases in grain yield of this crop (DIDONET, 2005). Among those practices, plant population and row spacing are included, which needs to be evaluated for each new genotype to maximize yield potential, as it is directly related to the yield components
(AZEVEDO et al., 2008; SANTOS et al., 2014; ARF et al., 2015). Embrapa Rice and Beans developed new genotypes of SEG (CNFC 15874 and CNFC 15875), these materials have indeterminate growth habit type II, with erect plants and little branched stems. CNFC 15874 has life cycle of 7075 days, which is around 5 days longer than CNFC 15875 genotype (65-70 days). Genotypes have similar response to deseases, they are resistant to common mosaic virus, susceptible to Fusarium spp. and have medium resistance to anthracnose (Colletotrichum lidemuthianum (Sacc. \& Magn.) Scrib). However, these genotypes were not evaluated for plant population. This variable has to be characterized in more detail in order to develop a management system that allows the fully exploitation to the genetic potential of the SEG. Therefore, the aim of this study was to determine the effects of spatial arrangements, plant population and row spacing, on grain yield and its components in super-early genotypes of common bean.

The field experiments were conducted for two consecutive growing seasons (summer 2014/2015 and winter 2015) at Capivara Farm, located in the city of Santo Antonio de Goiás, GO, Brazil. The geographical coordinates of the site are $16^{\circ} 28^{\prime} 00^{\prime \prime} \mathrm{S}$, 49o $17^{\prime} 00^{\prime \prime}$ West. The altitude of the site is $823 \mathrm{~m}$ above sea level. The climate is tropical savanna, considered Aw according to the Köppen classification. There are two well-defined seasons: usually, the rainy season extends from October to April (spring / summer) and the dry season from May to September (autumn / winter). The historic average annual rainfall ranges from 1500 to $1700 \mathrm{~mm}$ and average annual temperature from $14.2{ }^{\circ} \mathrm{C}$ to $34.8{ }^{\circ} \mathrm{C}$. Additionally, the daily average temperature and precipitation during the experiment were monitored (Figure 1). 

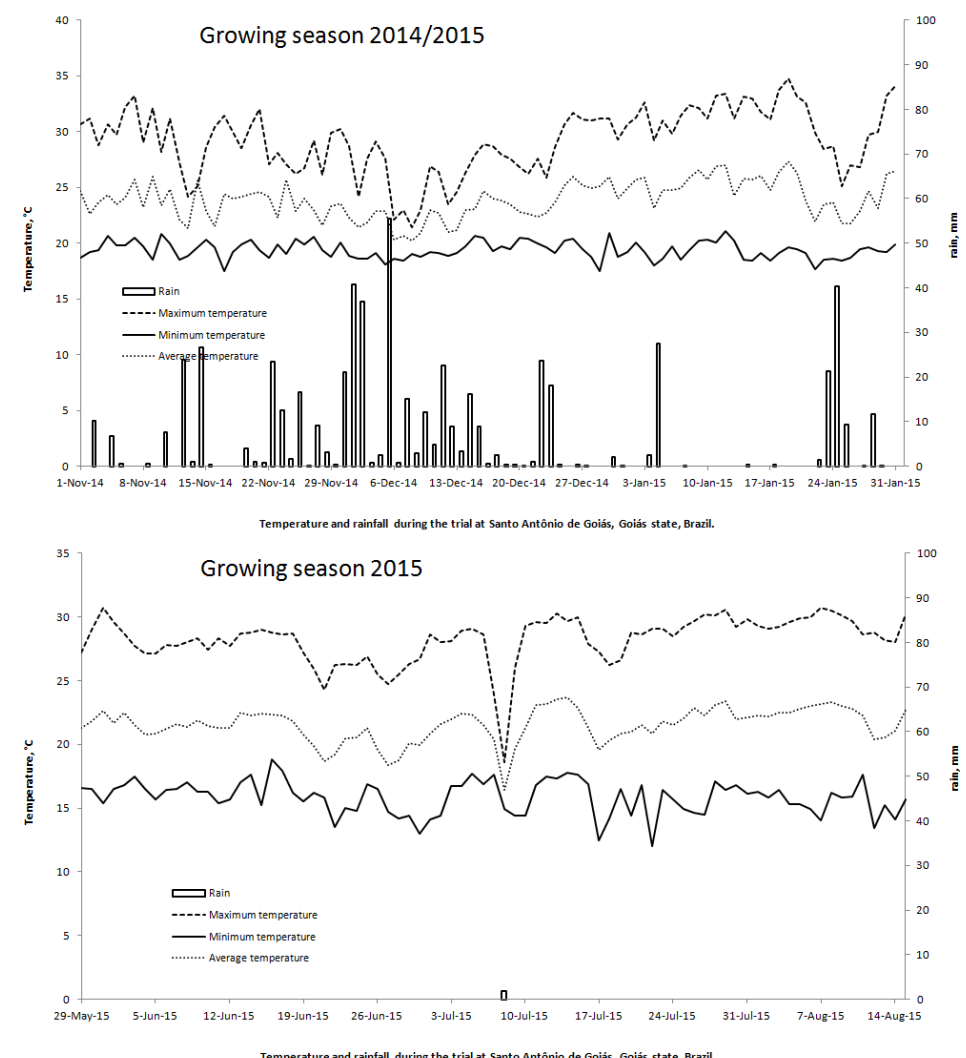

Figure 1. Maximum, minimum and average temperature and rainfall during the trials. Santo Antônio de Goiás, GO, Brazil, growing seasons summer 2014/2015 and winter 2015.

The soil was classified as a clay loam (kaolinitic, thermic Typic Haplorthox) acidic soil. Prior to the experiment, chemical characteristics of the soil were determined (Table 1). The soil analysis was performed according to Claessen (1997).

Trials were performed in different areas in each growing season. The experimental areas had been cultivated in a no-tillage system (NTS) since 2008. The last crop rotations were soybean (spring/summer), followed by maize (Zea mays L.) (summer) and the common bean (autumn/winter) for the trials cultivated in the winter (2015). In the trial performed in the summer (2014/2015), maize was cultivated in the last summer (2013/2014 growing season) and fallow in the off season. The corn and fallow shoot dry matter straw on the soil surface at common bean sowing was $8 \mathrm{Mg} \mathrm{ha}{ }^{-1}$ in the summer of 2014/2015 growing season and $12 \mathrm{Mg}$ $\mathrm{ha}^{-1}$ in the winter of 2015 growing season. 
Table 1. Chemical soil attributes from the experimental area. Santo Antônio de Goiás, GO, Brazil, growing seasons summer 2014/2015 and in the winter of 2015.

\begin{tabular}{|c|c|c|c|c|c|c|}
\hline \multicolumn{7}{|c|}{ Growing season $2014 / 2015$} \\
\hline Layer & $\mathrm{pH}$ & $\mathrm{Ca}$ & $\mathrm{Mg}$ & $\mathrm{Al}$ & $\mathrm{H}+\mathrm{Al}$ & SOM \\
\hline $\mathrm{cm}$ & in $\mathrm{H}_{2} \mathrm{O}$ & \multicolumn{4}{|c|}{$\mathrm{mmol}_{\mathrm{c}} \mathrm{kg}^{-1}$} & $\mathrm{~g} \mathrm{~kg}^{-1}$ \\
\hline $0-5$ & 6.0 & 21 & 16 & 0 & 41 & 39.92 \\
\hline $5-10$ & 6.1 & 21 & 12 & 0 & 51 & 35.37 \\
\hline $10-20$ & 5.6 & 12 & 7 & 1 & 48 & 31.71 \\
\hline Layer & $\mathrm{P}$ & $\mathrm{K}$ & $\mathrm{Cu}$ & $\mathrm{Zn}$ & $\mathrm{Fe}$ & $\mathrm{Mn}$ \\
\hline $\mathrm{cm}$ & \multicolumn{6}{|c|}{$\mathrm{mg} \mathrm{kg}^{-1}$} \\
\hline $0-5$ & 27.8 & 234 & 1.8 & 17.0 & 19.6 & 35.6 \\
\hline $5-10$ & 25.5 & 187 & 1.7 & 10.7 & 17.7 & 25.4 \\
\hline $10-20$ & 81.5 & 156 & 2.4 & 12.8 & 23.1 & 10.1 \\
\hline \multicolumn{7}{|c|}{ Growing season 2015} \\
\hline Layer & $\mathrm{pH}$ & $\mathrm{Ca}$ & $\mathrm{Mg}$ & Al & $\mathrm{H}+\mathrm{Al}$ & SOM \\
\hline $\mathrm{cm}$ & in $\mathrm{H}_{2} \mathrm{O}$ & \multicolumn{4}{|c|}{$\mathrm{mmol}_{\mathrm{c}} \mathrm{kg}^{-1}$} & $\mathrm{~g} \mathrm{~kg}^{-1}$ \\
\hline $0-5$ & 6.2 & 22.6 & 13.2 & 0 & 36 & 26.80 \\
\hline 5 a 10 & 5.7 & 6.1 & 3.9 & 3 & 33 & 23.35 \\
\hline 10 a 20 & 5.5 & 5.8 & 3.5 & 2 & 24 & 20.83 \\
\hline Layer & $\mathrm{P}$ & $\mathrm{K}$ & $\mathrm{Cu}$ & $\mathrm{Zn}$ & $\mathrm{Fe}$ & $\mathrm{Mn}$ \\
\hline $\mathrm{cm}$ & \multicolumn{6}{|c|}{$\mathrm{mg} \mathrm{kg}^{-1}$} \\
\hline $0-5$ & 22.5 & 139.0 & 1.5 & 4.4 & 38.2 & 9.0 \\
\hline 5 a 10 & 38.5 & 48.0 & 1.8 & 2.1 & 37.0 & 3.5 \\
\hline 10 a 20 & 13.0 & 45.0 & 1.7 & 1.9 & 27.3 & 3.7 \\
\hline
\end{tabular}

$\S$ SOM - soil organic matter.

The experimental design was a randomized complete block layout arranged in a $2 \times 2 \times 5$ factorial scheme, with six replicates in the summer of 2014/2015 and winter of 2015. The treatments consisted of the combination of two super-early genotypes of common bean (CNFC 15874 and CNFC 15875), two row spacing $(0.35$ and $0.45 \mathrm{~m})$ and five seed densities in the row $\left(6,10,14,18\right.$ and 22 seeds $\left.\mathrm{m}^{-1}\right)$. It was also included a control treatment, the IPR Colibri (6575 days of life cycle) with density of 10 seeds per meter. Genotypes were selected because are the more productive and promising to be used by the farmers (NASCENTE; MELO, 2015). The 4-row plots consisted of five-meter-long rows. The useful area of each plot was central four meters of the two central rows.

Approximately 15 days before sowing, the experimental area was desiccated with glyphosate $+2,4-D$. The base fertilization, to be applied in the sowing furrows, was calculated according to the soil's chemical characteristics and the recommendations of Sousa and Lobato (2004). The fertilizer consisted of $20 \mathrm{~kg} \mathrm{ha}^{-1}$ of $\mathrm{N}$ as urea, $105 \mathrm{~kg} \mathrm{ha}^{-1}$ of $\mathrm{P}_{2} \mathrm{O}_{5}$ (triple superphosphate) and $52.5 \mathrm{~kg} \mathrm{ha}^{-1}$ of $\mathrm{K}_{2} \mathrm{O}$ (potassium chloride) and was applied at sowing. Topdressing with $60 \mathrm{~kg} \mathrm{ha}^{-1}$ of $\mathrm{N}$ as urea was done at V4 stage of common bean (third trifoliolate leaf).

The sowing of the common bean varieties was performed mechanically using no-till trial planter on November $8^{\text {th }}, 2014$ and May $29^{\text {th }}$, 2015. Cultural practices were performed according to the recommendations for the crop to keep the area free of weeds, disease and insects. In the winter of 2015 a center pivot irrigation system was used. Common bean emergence occurred at five (2014/2015) and eight (2015) days after sowing. The average of the $V_{4}$ stage was at 13 and 15 days after emergence in the growing seasons 2014/2015 and 2015, respectively. The average growing season (length of time from emergence to harvest) was 65 days (January, 17 $7^{\text {th }} 2015$ ) and 75 days (August, 15 ${ }^{\text {th }}$ 2015), when harvest was performed manually, followed by mechanized tresher.

The harvested common bean grains were weighed, transformed to $\mathrm{kg} \mathrm{ha}^{-1}$ and yield expressed on a $13 \%$ of water content. Additionally, the following yield components 
were assessed: the number of pods per plant, number of grains per pod (recorded on 10 plants per plot that were chosen at random), and the weight of 100 grains (calculated from eight random samples per plot).

The data were subjected to analysis of variance (PROC GLM), and the means were compared by Tukey's test at $p \leq 0.05$. Dunnett's test was performed at a significance level of $p \leq 0.05$ to compare the control treatment (IPR Colibri) with each genotype (CNFC 15874 and CNFC 15875) at each planting density $(6,10,14$, 18 and 22 seeds $\mathrm{m}^{-1}$ ). When planting density was significant for variables evaluated (number of pods per plant, number of grains per pod, mass of grains or grain yield), it was performed regression analysis between plant density $(6,10$, 14,18 and 22 seeds $\mathrm{m}^{-1}$ ) and the variable that was significant. These analyses were made with SAS statistical program.

For number of pods per plant, a significant effect of sowing density and row spacing was detected in 2014/2015 (Table 2). In the winter of 2015 , there was only a single effect of sowing density in this variable (Table 3).

Table 2. Number of pods per plant (NPP), number of grains per pods (NGP), mass of 100 grains (M100) and grain yield (GY) of super-early genotypes of common bean as affected by sowing density and row spacing. Santo Antônio de Goiás, GO, Brazil, growing season summer 2014/2015.

\begin{tabular}{|c|c|c|c|c|}
\hline Treatments & NPP & NGP & M100 & GY \\
\hline Genotypes & number & number & g & $\mathrm{kg} \mathrm{ha}^{-1}$ \\
\hline CNFC 15874 & 9 & $4.4 \mathrm{a}$ & $23.1 \mathrm{~b}$ & 3129 \\
\hline CNFC 15875 & 9 & $3.9 \mathrm{~b}$ & $24.6 \mathrm{a}$ & 2763 \\
\hline \multicolumn{5}{|l|}{ Sowing density (plants $\mathrm{m}^{-1}$ ) } \\
\hline 6 & 10 & 4.4 & 24.7 & 1653 \\
\hline 10 & 8 & 4.1 & 23.5 & 1934 \\
\hline 14 & 9 & 4.1 & 23.6 & 2839 \\
\hline 18 & 8 & 4.2 & 23.1 & $3692 *$ \\
\hline 22 & 8 & 4.0 & 24.2 & $4614^{*}$ \\
\hline IPR Colibri (10 plants $\mathrm{m}^{-1}$ ) & 8 & 4.0 & 24.2 & 2055 \\
\hline \multicolumn{5}{|l|}{ Row spacing $(\mathrm{m})$} \\
\hline 0.35 & $8 \mathrm{~b}$ & 4.1 & 24.0 & $2879 \mathrm{~b}$ \\
\hline 0.45 & $10 \mathrm{a}$ & 4.2 & 23.7 & $3013 a$ \\
\hline Factors & \multicolumn{4}{|c|}{ ANAVA (F probability) } \\
\hline Genotypes (G) & 0.9802 & 0.0031 & 0.0028 & 0.0428 \\
\hline Sowing density (SD) & 0.0467 & 0.5376 & 0.2486 & $<0.001$ \\
\hline Row spacing (RS) & 0.0094 & 0.2913 & 0.5590 & 0.6944 \\
\hline $\mathrm{G} * \mathrm{SD}$ & 0.8116 & 0.9055 & 0.7730 & 0.7707 \\
\hline$G * R S$ & 0.2484 & 0.1618 & 0.1644 & 0.4070 \\
\hline$S D * R S$ & 0.9982 & 0.2740 & 0.3083 & 0.8212 \\
\hline $\mathrm{G} * \mathrm{SD} * \mathrm{RS}$ & 0.6176 & 0.0630 & 0.3937 & 0.6202 \\
\hline
\end{tabular}

${ }^{+}$Means followed by the same letter in the column do not differ by Tukey test at $p<0.05$. ${ }^{*}$ Means followed by this symbol, differ from control by Dunnett's test for $p<0.05$.

The larger row spacing $(0.45 \mathrm{~m})$ provided higher values of number of pods per plants. Regarding sowing density in both growing seasons there were tendency to reduce the number of pods as increased the number of plants per meter (Figures 2 and 3). With the increase in the number of plants per meter, it is likely to have occurred more competition between plants for environmental resources, which was reflected in the reduction of number of pods per meter. On the other hand, when increasing row spacing, it is likely that reduced the plant competition and allowed increases in the number of pods. According to Quintero (1986), Arf et al. (1996), Jadoski et al. (2000) and Freitas et al. (2013) it is expected that more 
plants per area entails the increased competition for light and photoassimilates between them.

In the growing season 2014/2015 there was not effect of number of grains per pods and mass of 100 grains (Table 2). However, there was significant effect of sowing density and row spacing for grain yield. In the winter season of 2015 there were effects of sowing density in all yield components (Table 3 ). Therefore, in the winter growing season of 2015, it was possible to see reduction in the values of yield components when increasing the number of seeds per meter (Figure 3). Azevedo et al. (2008), also observed reduction in the number of pods per area and mass of 100 grains in common bean when they increased the plant population per area. In the same way, Souza et al. (2014) reported that increasing plants per area provided reduction in the number of pods per plants. Otherwise, Buso et al. (2013) found that the increase of seeding density did not change yield components for common bean varieties.

Table 3. Number of pods per plant (NPP), number of grains per pods (NGP), mass of 100 grains (M100) and grain yield (GY) of super early genotypes of common bean as affected by sowing density and row spacing. Santo Antônio de Goiás, GO, Brazil, growing season winter 2015.

\begin{tabular}{|c|c|c|c|c|}
\hline Treatments & NPP & NGP & M100 & GY \\
\hline Genotypes & number & number & g & $\mathrm{kg} \mathrm{ha}^{-1}$ \\
\hline CNFC 15874 & 11 & 4.7 & 26.3 & 2413 \\
\hline CNFC 15875 & 12 & 4.2 & 26.7 & 2412 \\
\hline \multicolumn{5}{|l|}{ Sowing density (plants $\mathrm{m}^{-1}$ ) } \\
\hline 6 & $16^{*}$ & 4.7 & $27.6^{*}$ & 2239 \\
\hline 10 & 12 & 4.5 & 26.6 & 2322 \\
\hline 14 & 11 & 4.4 & 26.3 & 2455 \\
\hline 18 & $9 *$ & 4.5 & 26.0 & $2506^{*}$ \\
\hline 22 & $8.0^{*}$ & 4.3 & 25.8 & $2537^{*}$ \\
\hline IPR Colibri (10 plants $\mathrm{m}^{-1}$ ) & 13 & 4.3 & 25.3 & 2196 \\
\hline \multicolumn{5}{|l|}{ Row spacing $(\mathrm{cm})$} \\
\hline 0.35 & 11 & 4.5 & 26.8 & $2107 b^{+}$ \\
\hline 0.45 & 12 & 4.4 & 26.1 & 2717 a \\
\hline Factors & \multicolumn{4}{|c|}{ ANAVA (F probability) } \\
\hline Genotypes (G) & 0.0587 & 0.0587 & 0.2353 & 0.9818 \\
\hline Sowing density (SD) & $<0.0001$ & 0.0445 & 0.0063 & 0.0039 \\
\hline Row spacing (RS) & 0.2497 & 0.3571 & 0.0598 & $<0.0001$ \\
\hline $\mathrm{G} * \mathrm{SD}$ & 0.1947 & 0.9142 & 0.6900 & 0.9337 \\
\hline G*RS & 0.3891 & 0.3571 & 0.1577 & 0.2250 \\
\hline$S D * R S$ & 0.5936 & 0.9502 & 0.9537 & 0.0561 \\
\hline $\mathrm{G} * \mathrm{SD} * \mathrm{RS}$ & 0.3219 & 0.5340 & 0.5118 & 0.8289 \\
\hline
\end{tabular}

${ }^{+}$Means followed by the same letter in the column do not differ by Tukey test at $p<0.05$. ${ }^{*}$ Means followed by this symbol, differ from control by Dunnett's test for $p<0.05$.

Regarding grain yield of common bean, it was found significant increases in both growing season, summer 2014/2015 and in the winter of 2015 (Figures 2 and 3). The common bean grain yield is a function of its yield components number of pods per plant, number of grains per pod and mass of 100 grains multiplied by the plant population (ARAÚJO et al., 1996). The number of pods per plant and number of grains per pods are considered the yield component most affected by seeding densities variations and row spacing (SHIMADA et al., 2000). 

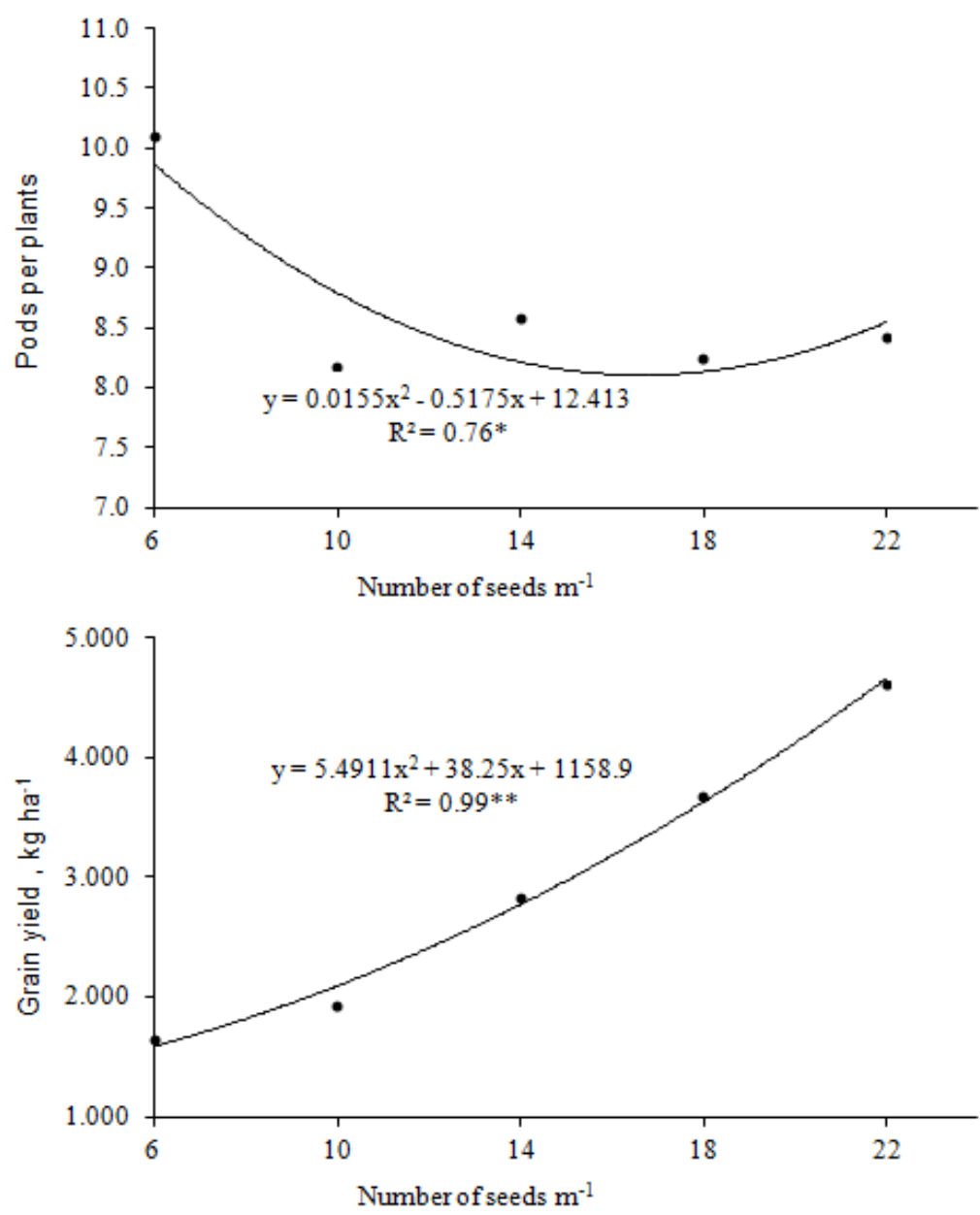

Figure 2. Number of pods per plant and grain yield of super-early genotypes of common bean as a function of sowing density. Santo Antônio de Goiás, GO, Brazil, growing season summer 2014/2015.
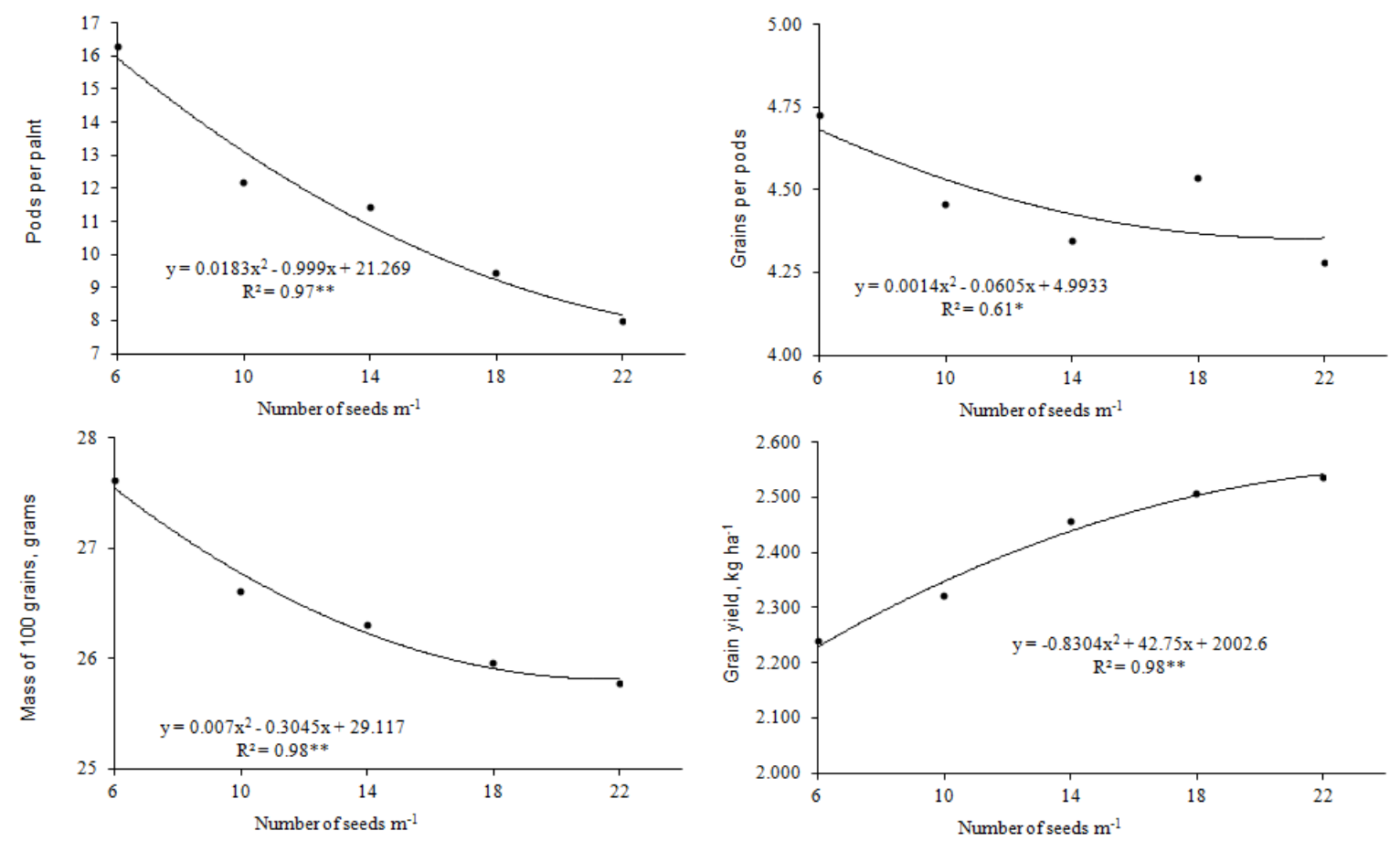

Figure 3. Number of pods per plant, number of grains per pods, mass of 100 grains and grain yield of superearly genotypes of common bean as a function of sowing density. Santo Antônio de Goiás, GO, Brazil, growing season winter 2015. 
Although the yield components were reduced per plant, when increased the number of plants it provided also increased in the grain yield. Therefore, the best results aiming higher grain yield wan observed when it was sowed 22 plants per meter. The increase in plant population in most common bean varieties provides increases in grain yield (EDJE et al., 1975; BENNETT et al., 1977; JADOSKI et al., 2000). However, Santos et al. (2014) found that the increase in seeding densities for common bean did not affect grain yield, Alves et al. (2009) found that the increase of plant population reduced the

\section{CONCLUSION}

The increase in plant density decreased the yield components per plant but increased grain yield of super-early genotypes of common bean per area;

\section{REFERENCES}

ALVES, A. F.; ANDRADE, M. J. B.; RODRIGUES, R. M.; VIEIRA, N. M. B. Population densities for alternative cultivars of bean in northern Minas Gerais. Ciência e Agrotecnologia, v.33, p.14951502, 2009. https://doi.org/10.1590/S1413$\underline{70542009000600006}$

ARAÚJO, R. S.; RAVA, C. A.; STONE, L. F.; ZIMMERMANN, M. J. Cultura do feijoeiro comum no Brasil. Piracicaba: Associação Brasileira para Pesquisa de Potassa e do Fosfato, 1996. 786p.

ARF, O.; SÁ, M. E.; OKITA, C. S. Effect of different spacing and densities of sowing on the development of beans (Phaseolus vulgaris L.). Pesquisa Agropecuária Brasileira, v.3, p.629-634, 1996.

ARF, O.; RODRIGUES, R. A. F.; NASCENTE, A.S.; LACERDA, M. C. Espaçamento e adubação nitrogenada afetando o desenvolvimento do arroz de terras altas sob plantio direto. Revista Ceres, v. 62, p. 475-482, 2015. https://doi.org/10.1590/0034$\underline{737 \times 201562050008}$

AZEVEDO, J. A.; SILVA, E. M.; RODRIGUES, G. C.; GOMES, A. C. Produtividade do feijão de inverno influenciada por irrigação, densidade de plantio e adubação em solo de Cerrado. Planaltina: Embrapa Cerrados, 2008. number of pods and grains per plant, however, did not influence the grain yield, and Costa et al. (2009) found the maximum grain yield when reducing the seeding densities. The row spacing that provided higher grain yield was at $0.45 \mathrm{~m}$. Didonet and Costa (2004) studying plant population and row spacing for early varieties of common bean found $0.40 \mathrm{~m}$ as the spacing with maximum yield, when compared to 0.30 and 0.50 $\mathrm{m}$. These results are attributed to the increased competition of the plants by means of the resources.

The sowing density of 22 seeds per meter and with $0.45 \mathrm{~m}$ of row spacing allows the highest grain yield in super-early genotypes of common

bean.

BENNET, J. P.; ADAMS, M. W.; BURGA, C. Pod yield component variation and intercorrelation in (Phaseolus vulgaris L.) as affected by planting density. Crop Science, v.17, p.73-75, 1977. https://doi.org/10.2135/cropsci1977.0011183X0 $\underline{01700010021 x}$

BUSO, W. H. D.; SILVA, L. B.; RIOS, A. D. F. Bean production components in two periods of planting in the central region of Goiás. Agrarian, v.7, p.205-210, 2013.

CLAESSEN, M. E. C. Manual de métodos de análise de solo. 2.ed. Rio de Janeiro: EMBRAPACNPS, 1997. 212p.

CONAB. Acompanhamento da safra brasileira: Grãos. 2016. Disponível em: <http://www.conab.gov.br/OlalaCMS/uploads/ar quivos/15_01_09_09_00_21_boletim_graos_jane iro_2015.pdf>. Acesso em: 08 de fev. 2016.

COSTA, R. S. S.; ARF, O.; ORIOLI-JÚNIOR, V.; BUZETTI, S. Plants population and nitrogen for common bean in no-tillage system. Caatinga, v.22, p.39-45, 2009.

DIDONET, A. D. Ecofisiologia e rendimento potencial do feijoeiro. In: DEL PELOSO, M.J.; MELO, L.C. (Eds). Potencial de rendimento da cultura do feijoeiro comum. Santo Antônio de Goiás : Embrapa Arroz e Feijão, 2005. p.9-37. 
DIDONET, A. D.; COSTA, J. G. C. Plant population and yield of early dry beans. Pesquisa Agropecuária Tropical, v.34, p.105-109, 2004.

EDJE, O. T.; MUCHOCHO, L. K.; AYONOADU, U. W. $U$. Bean yield and yield components as affected by fertilizer and plant population. Turrialba, v.25, p.79-84, 1975.

FAOSTAT. Production: Crops. 2016. Disponível em: <www.faostat.fao.org>. Acesso em: 29 abr. 2016.

FREITAS, R. J.; NASCENTE, A. S.; SANTOS, F. L. S. Population of maize plants intercropped with Urochloa ruziziensis. Pesquisa Agropecuária Tropical, v.43, p.79-87, 2013. https://doi.org/10.1590/S1983-

40632013000100011

JADOSKI, S. O.; CARLESSO, R.; WOISCHICK, D.; PETRY, M. T.; FRIZZO, Z. Plant population and row spacing for irrigated drybean II: grain yield and yield components. Ciência Rural, v.30, p.567-573, $2000 . \quad$ https://doi.org/10.1590/5010384782000000400002

NASCENTE, A. S.; MELO, L. C. Characterization of early genotypes of common bean. Annual Report of the Bean Improvement Cooperative, v.58, p.119-120, 2015.

NASCENTE, A. S.; MELO, L. C.; ROSA, P. H. . Growth analysis of early genotypes of common beans. Annual Report of the Bean Improvement Cooperative, v. 51, p. 249-250, 2016.

QUINTERO, E. La densidad de poblacion y distribución espacial en el crescimento y rendimento dei frijol común (Phaseolus vulgaris L.). Cultivos Tropicales, v.8, p.23-32, 1986.
ROSALES-SERNA, R.; KOHASHI-SHIBATA, J.; ACOSTA-GALLEGOS, J. A. Biomass distribution, maturity acceleration and yield in droughtstressed common bean cultivars. Field Crops Research, v.85, p.203-211, 2004. https://doi.org/10.1016/S0378-4290(03)00161-8

SANTOS, M. G. P.; CARVALHO, A. J.; DAVID, A. M. S. S.; AMARDO, H. T. R.; VIEIRA, N. M. B.; SOUZA, V. B.; CARNEIRO, J. E. S. Seeding rates and seasons of cultivation on growth performance of cultivars of common bean. Semina: Ciências Agrárias, v.35, p.2309-2324, 2014. https://doi.org/10.5433/1679-

$\underline{0359.2014 v 35 n 5 p 2309}$

SHIMADA, M.; SÁ, M. E.; ARF, O. Yield components and crop growth of common bean under different plant densities. Bragantia, v.59, p.181-187, 2000. https://doi.org/10.1590/S0006$\underline{87052000000200009}$

SOUSA, D. M. G.; LOBATO, E. Cerrado: correção do solo e adubação. 2.ed. Embrapa-Cerrados, Brasília, 2004. 416p.

SOUZA, A. B.; OLIVEIRA, D. P.; SILVA, C. A.; ANDRADE, M. J. B. Populações de plantas e doses de nitrogênio para o feijoeiro em sistema convencional. Bioscience Journal, v. 30, p.9981006, 2014.

Recebido para publicação em 13/02/2017

Revisado em 08/06/2016

Aceito em 15/06/2017 